\title{
The Additional Mycorrhization Effect on the Development of Potato Plants
}

\author{
Ioana Daniela BORCA ${ }^{1}$, Carmen Emilia PUIA ${ }^{1 *}$ \\ ${ }^{1)}$ Faculty of Agriculture, Department of Environmental and Plant Protection, University of Agricultural \\ Sciences and Veterinary Medicine, Manastur Street, No. 3-5, 400372, Cluj-Napoca, Romania \\ * corresponding author: carmen.puia@yahoo.com
}

Bulletin USAMV series Agriculture 71(2)/2014

Print ISSN 1843-5246; Electronic ISSN 1843-5386

DOI 10.15835/buasvmcn-agr: 10594

\begin{abstract}
The height and the leaf area of three potato varieties, in two sequences of vegetation (30 and 50 days after planting) were analysed in order to mark the effect of the additional mycorrhization on the potato plants. The development of the potato plants was positively influenced by the additional inoculation with mycorrhizal fungi. In this conditions the plants height varied between $19.67 \mathrm{~cm}$ and $25 \mathrm{~cm}$ on the first sequence of vegetation and $58 \mathrm{~cm}$ and $63 \mathrm{~cm}$ on the second sequence of vegetation. Related to the leaf area development of the potato plants under additional mycorrhization, at 30 days after planting this parameter ranged between $211.68 \mathrm{~cm}^{2}$ and 256.63 $\mathrm{cm}^{2}$ and $341.13 \mathrm{~cm}^{2}$ and $624.93 \mathrm{~cm}^{2}$ at 50 days after planting.
\end{abstract}

Keywords: arbuscular mycorrhiza, plants, potato

Introduction. Arbuscular mycorrhizal (AM) fungi have been widely recognized as biological control agents (Barea et al., 2005). They play a key role in the plant nutrition and growth, in the resistance to drought and in the soil structure. These soil microorganisms have been used to control plant diseases thus improving plant resistance (Smith and Read, 2008).

Aims and objectives. We studied the influence of the additional mycorrhization in the development of potato plants by measured the height $(\mathrm{cm})$ and leaf area $\left(\mathrm{cm}^{2}\right)$.

Materials and methods. The experimental plot was located in Rascruci, Cluj County, Romania. For the research experiment it was used the method of subdivided plots. To establish the effect of the additional colonization on the plants growth parameters were made observations on two sequences of vegetation at 30 and 50 days after planting. The followed parameters were: the plant height $(\mathrm{cm})$ and the leaf area $\left(\mathrm{cm}^{2}\right)$ of three potato varieties: early variety (Roclas), semi-early variety (Christian) and late variety (Gared). For the inoculum it was used a mixture of arbuscular mycorrhizal fungi (200.000 propagules per liter, material of AM fungi, concentrated on an inorganic carrier).

Results and Discussions. On the first sequence of vegetation (Tab. 1) the additional mycorrhization has a positive effect regarding the height of plants for all the three studied varieties. All of them presented significant positive differences to the control, under additional inoculation. The least influenced variety was the semi-early one.

At 50 days after planting (Tab. 2) only the early variety was positively influenced by the mycorrhizal inoculation.

Regarding the leaf area of the potato plants, the additional mycorrhization had a positive influence on all three studied varieties. At 30 days after planting (Tab. 3) for the early variety of potato has been reported a very significant positive difference to the control and it also presented the highest favourability. On the second sequence of vegetation (Tab. 4), at 50 days after planting, was noted that the mycorrhizal inoculation influenced positively only the early and semi-early variety while the late variety showed no significant differences to the control. 
Tab. 1. Additional mycorrhization effect on the height of potato plants in first sequence of vegetation

\begin{tabular}{|c|c|c|c|c|c|c|c|}
\hline Variety & & $\begin{array}{c}\text { Mycorrhization } \\
\text { type }\end{array}$ & $\begin{array}{c}\text { Plant } \\
\text { height }\end{array}$ & $\begin{array}{c}\% \text { to } \\
\text { control }\end{array}$ & $\begin{array}{l}\text { Difference } \\
\text { to control } \\
\end{array}$ & $\begin{array}{c}\text { Difference } \\
\text { significance } \\
\end{array}$ & $\begin{array}{c}\text { Duncan } \\
\text { test }\end{array}$ \\
\hline Varieties average & & natural & 15.67 & 100 & 0 & Mt. & - \\
\hline \multirow{2}{*}{ Early } & & natural & 19 & 121.3 & 3.33 & - & $\mathrm{BC}$ \\
\hline & & additional & 24.33 & 155.3 & 8.67 & $* * *$ & $\mathrm{D}$ \\
\hline \multirow[t]{2}{*}{ Semi-early } & & natural & 13.67 & 87.2 & -2 & - & $\mathrm{A}$ \\
\hline & & additional & 19.67 & 125.5 & 4 & $*$ & $\mathrm{C}$ \\
\hline \multirow[t]{3}{*}{ Late } & & natural & 14.33 & 91.5 & -1.33 & - & A \\
\hline & & additional & 25 & 159.6 & 9.33 & $* * *$ & $\mathrm{D}$ \\
\hline & LSD (p 5\%) 3.62 & LSD (p1\%) & 5.21 & LSD (p 0.1\%) & 7.72 & & \\
\hline
\end{tabular}

Tab. 2. Additional mycorrhization effect on the height of potato plants in second sequence of vegetation

\begin{tabular}{lcccccc}
\hline Variety & $\begin{array}{c}\text { Mycorrhization } \\
\text { type }\end{array}$ & $\begin{array}{c}\text { Plant } \\
\text { height }\end{array}$ & $\begin{array}{c}\% \text { to } \\
\text { control }\end{array}$ & $\begin{array}{c}\text { Difference } \\
\text { to control }\end{array}$ & $\begin{array}{c}\text { Difference } \\
\text { significance }\end{array}$ & $\begin{array}{c}\text { Duncan } \\
\text { test }\end{array}$ \\
\hline Varieties average & natural & 56.55 & 100 & 0 & Mt. & - \\
\hline Early & natural & 47.33 & 83.7 & -9.22 & 0 & $\mathrm{~A}$ \\
\hline & additional & 62.33 & 110.2 & 5.78 & $*$ & $\mathrm{BC}$ \\
\hline Semi-early & natural & 63.33 & 112 & 6.78 & $*$ & $\mathrm{C}$ \\
\hline Late & additional & 63 & 111.4 & 6.45 & $*$ & $\mathrm{C}$ \\
\hline & natural & 59 & 104.3 & 2.45 & - & $\mathrm{BC}$ \\
\hline & additional & 58 & 102.6 & 1.45 & - & $\mathrm{BC}$ \\
\hline
\end{tabular}

Tab. 3. Additional mycorrhization effect on the leaf area of potato plants in first sequence of vegetation

\begin{tabular}{|c|c|c|c|c|c|c|}
\hline Variety & $\begin{array}{c}\text { Mycorrhization } \\
\text { type }\end{array}$ & $\begin{array}{l}\text { Leaf } \\
\text { area }\end{array}$ & $\begin{array}{c}\% \text { to } \\
\text { control }\end{array}$ & $\begin{array}{l}\text { Difference } \\
\text { to control }\end{array}$ & $\begin{array}{c}\text { Difference } \\
\text { significance }\end{array}$ & $\begin{array}{c}\text { Duncan } \\
\text { test }\end{array}$ \\
\hline Varieties average & natural & 163.14 & 100 & 0 & Mt. & - \\
\hline \multirow[t]{2}{*}{ Early } & natural & 198.45 & 121.6 & 35.31 & - & $\mathrm{BC}$ \\
\hline & additional & 256.63 & 157.3 & 93.49 & $* * *$ & D \\
\hline \multirow[t]{2}{*}{ Semi-early } & natural & 161.73 & 99.1 & -1.41 & - & $\mathrm{AB}$ \\
\hline & additional & 211.68 & 129.7 & 48.53 & $*$ & $\mathrm{C}$ \\
\hline \multirow[t]{2}{*}{ Late } & natural & 129.21 & 79.2 & -33.93 & - & A \\
\hline & additional & 221.62 & 135.8 & 58.48 & * & $\mathrm{CD}$ \\
\hline
\end{tabular}

Tab. 4. Additional mycorrhization effect on the leaf area of potato plants in second sequence of vegetation

\begin{tabular}{|c|c|c|c|c|c|c|}
\hline Variety & $\begin{array}{c}\text { Mycorrhization } \\
\text { type }\end{array}$ & $\begin{array}{r}\text { Leaf } \\
\text { area }\end{array}$ & $\begin{array}{c}\% \text { to } \\
\text { control }\end{array}$ & $\begin{array}{l}\text { Difference } \\
\text { to control }\end{array}$ & $\begin{array}{c}\text { Difference } \\
\text { significance }\end{array}$ & $\begin{array}{c}\text { Duncan } \\
\text { test }\end{array}$ \\
\hline Varieties average & natural & 374.31 & 100 & 0 & Mt. & - \\
\hline \multirow{2}{*}{ Early } & natural & 400.63 & 107 & 26.32 & - & $\mathrm{A}$ \\
\hline & additional & 624.93 & 167 & 250.62 & $* * *$ & $\mathrm{C}$ \\
\hline \multirow[t]{2}{*}{ Semi-early } & natural & 387.72 & 103.6 & 13.52 & - & $\mathrm{A}$ \\
\hline & additional & 513.19 & 137.1 & 138.88 & $* *$ & $\mathrm{~B}$ \\
\hline \multirow[t]{2}{*}{ Late } & natural & 334.58 & 89.4 & -39.73 & - & $\mathrm{A}$ \\
\hline & additional & 341.13 & 91.1 & -33.18 & - & $\mathrm{A}$ \\
\hline
\end{tabular}

Conclusion. In the present research work, we demonstrated that the additional mycorrhization had a positive influence on the development of the potato plants in both considered sequences of vegetation. The potato variety most strongly influenced by additional inoculation, was the early variety followed by the semi-early variety.

\section{REFERENCES}

1. Barea J.M., M.J. Pozo, R. Azcon, C. Azcon-Aguilar (2005). Microbial cooperation in the rhizosphere. J. Exp. Bot., 56:1761-1778

2. Smith S.E., D.J. Read (2008). Mycorrhizal symbiosis. $3^{\text {rd }}$ edit., London: Academic Press. p. 787. 